\title{
STEM CELL CHARACTERISTICS OF OVARIAN GRANULOSA CELLS - REVIEW*
}

\author{
Ewa Chronowska \\ Department of Biology of Reproduction and Molecular Genetics, Institute of Animal Science, \\ Přátelství 815, 10400 Prague-Uhř́něves, Czech Republic \\ Corresponding author: chronowska.ewa@gmail.com
}

\begin{abstract}
Recently increasing interest in stem cells of mammalian ovary has been observed. Potential somatic stem cells for the follicular theca and ovarian surface epithelium have been demonstated. On the other hand, despite intensive research, difinitive evidence for stem cell characteristics of granulosa cells is still to be found. Elucidation of stem cell properties of follicular granulosa cells may have important implications both from scientific and clinical point of view. The aim of this work is to review the current knowledge about stem cell properties of cells constituting main somatic compartment of the mammalian ovary, namely granulosa cells.
\end{abstract}

Key words: ovary, granulosa cells, stem cells, pluripotency, multipotency

During folliculogenesis in mammals, oocytes grow while surrounded by an increasing number of granulosa cell (GC) layers. From the preantral stage, theca cells differentiate as the outer layer of the follicle. These elements provide structural integrity and the androgen substrate for granulosa cell estrogen production (Honda et al., 2007). In many mammalian species primordial follicle growth, once initiated, continues until the follicle either becomes atretic ( $>99.9 \%)$ or proceeds to ovulation. Although the gonadotrophic regulation of antral follicle development has been studied in detail, the role of local factors is less well known. In recent years, however, significant progress has been made in understanding the complex intraovarian control mechanisms (Hunter and Paradis, 2009).

The complex biology of granulosa and theca cells suggests clearly the involvement of stem cell based mechanisms during the follicular development. Both the rapid proliferation of the granulosa cells of the growing follicle and the existence of

\footnotetext{
*Source of financing: grant of the MZE 0002701401 from the Ministry of Agriculture of the Czech Republic.
} 
a large variety of specialized functions can only be attributed to the fact that the population of GC in a healthy follicle is not uniform but rather consists of subpopulations of differentiated and less differentiated cells (Kossowska-Tomaszczuk et al., 2009). Elucidation of stem/progenitor function in the somatic compartment of the ovary may help to understand mechanisms of tumorigenesis resulting in important clinical implications. Stem status of the cell is characterized by the following features: pluripotency or multipotency, cell asymmetric division and indefinite self renewal (Wobus and Boheler, 2005).

\section{The origin and pluri/multipotency of granulosa cells}

The origin of the somatic cells of the primordial follicle surrounding the oocyte is not completely known but evidence indicates three possible sources: the developing ovarian surface epithelium (Gondos, 1975), the developing ovarian blastema (Pinkerton et al., 1961), and the mesonephric cells of the rete ovarii (Byskov and Lintern-Moore, 1973). It was postulated by Rodgers et al. (1999) that during follicular growth granulosa cells arise from the population of stem cells. According to the mentioned authors, during follicular development granulosa cells conform to the model in which the progeny of stem cells, the so called transit amplifying cells, can further replicate a limited number of times before they finally differentiate into specialized cells. Since more than one specialized type can often be formed, true or even committed stem cells are totipotent or pluripotent. Rodgers et al. (1999) pointed out that some granulosa cells exhibit functional properties of stem cells that include lack of inhibition of mitosis as a result of cellular contact, the ability to divide without anchorage to a substratum in vitro (Potten and Loeffler, 1990; Cooper, 1997) and pluripotency. It was experimentally proved that a small proportion of granulosa cells isolated from antral follicles can divide and form colonies when cultured in soft agar or methylcellulose solution (Rodgers et al., 1995 a), neither of which provide a substratum for anchorage. It was also suggested that lack of contact inhibition occurs in vivo during growth of a follicle particularly at the early, preantral stages where granulosa cells are in close physical contact, and in antral follicles where cells divide within the middle layers of the membrana granulosa (Rodgers et al., $1995 \mathrm{~b}$ ). Moreover, as a further evidence demonstrating a lack of contact inhibition of cell replication, granulosa cells cultured on a solid substratrum, but in the medium without serum containing attachment factors such as fibronectin readily form aggregates or hills (Rodgers et al., 1999; Gutierrez et al., 1997).

Recently, Kossowska-Tomaszczuk et al. (2009) demonstrated that luteinizing granulosa cells obtained from ovarian follicles of infertile patients and sorted with flow cytometry on the basis of expression of follicle stimulating hormone receptor could be maintained in the culture over prolonged period of time in the presence of leukemia inhibitory factor (LIF). During the culture the markers of granulosa cell function, such as aromatase enzyme and follicle stimulating hormone receptor gradually disappeared. On the other hand Oct-4 (POU domain, class 5, homeobox 1), a typical stem cell marker was expressed in the culture. Moreover, the multipotency of a subpopulation of GCs was established by in vitro differentiation into other cell types, such as neurons, chondrocytes, and osteoblasts. Follicle-derived stem cells 
were also able to survive when transplanted into the backs of immunoincompetent mice, in vivo generating tissues of mesenchymal origin. Using pig model, Chronows$\mathrm{ka}$ and Kott (2011 b) found that granulosa cells derived from mid-size follicles can be cultured for a prolonged period (up to 18 days) in the presence of basic fibroblast growth factor. In these conditions granulosa cells maintain their proliferative potential and telomerase activity and show reduced degree of differentiation measured by aromatase expression.

\section{Telomerase activity in granulosa cells}

Evidence for stem properties comes also from the ability of the cell to express telomerase. Telomerase is an enzyme responsible for protecting the chromosomes from shortening which takes place during each cell division. Normal somatic cells do not show telomerase activity. On the other hand it is expressed at a high level in cancer cells and in stem cells (Dashe et al., 1997). A limited amount of knowledge exists about the expression and the role of telomerase in developing ovarian follicles, and particularly in granulosa cells. In the bovine ovary (Lavranos et al., 1999) telomerase RNA component was localized to granulosa cells of growing follicles but was not detected in primordial follicles. Telomerase activity (TA) was the highest in the smallest examined follicles $(60-100 \mu \mathrm{m})$, decreasing significantly as the follicles enlarged. Significantly decreased telomerase activity was observed in large and atretic follicles versus small and healthy follicles in rat (Yamagata et al., 2002). In the human, decline of telomerase activity in the ovary was found to be related to primordial follicle loss with age (Kinugawa et al., 2000). Goto et al. (2011) observed that the relative telomere lengths and telomerase activity of the granulosa cells from old cows tended to be shorter than those of the cells from young cows. In primary and preantral follicles of pig ovary TERT (telomerase reverse transcriptase) was localized in granulosa and in germ cells, with a typical nuclear location (Russo et al., 2006). Tomanek et al. (2008) detected telomerase activity in pig granulosa cells obtained from small $(1-2 \mathrm{~mm})$ and large $(5-7 \mathrm{~mm})$ follicles. TA was observed in freshly isolated as well as cultured granulosa cells.

\section{Regulation of telomerase activity in granulosa cells}

Dynamics of telomerase expression in proliferating and differentiating tissues is regulated by growth factors, hormones and cellular microenvironment. In pig, epidermal growth factor (EGF) was shown to stimulate telomerase activity in small and large follicle granulosa cells (Tomanek et al., 2008). Yamagata et al. (2002) found significantly lower levels of telomerase activity in rat large and atretic ovarian follicles in comparison to TA level in small, healthy follicles. This observation suggests that estradiol produced by healthy follicles is an important factor controlling telomerase expression in GC. On the other hand, telomerase seems to be involved in maintaining the survivability of granulosa cells. Chronowska et al. (2010) determined the role of estrogen receptor in the modulation of telomerase activity in pig granulosa cells. In the presence of estrogen receptor $\alpha$ and $\beta$ inhibitor GC telomerase activity and estradiol synthesis was increased while proliferative potential was decreased. In the presence of aromatase inhibitor (Chronowska et al., 2009) telomerase activity in 
pig large follicle granulosa cells was decreased which suggests the important role of estrogens in the control of telomerase activity mainly during later stages of folliculogenesis. Very recently, Chronowska and Kott (2011) observed the stimulatory effect of androgen receptor antagonist (flutamide) on telomerase activity in porcine granulosa cells obtained from small and large follicles.

\section{Granulosa cells as nuclear donors in cloning experiments}

During differentiation, somatic nuclei acquire highly specialized DNA and chromatin modifications. Presently, several methods exist which allow reprogramming differentiated cells to the pluripotent status (generation of induced pluripotent stem cells [IPS], fusion of pluripotent embryonic stem cells with differentiated somatic cells, somatic cell nuclear transfer into oocytes). In order to achieve totipotency, upon somatic nuclear transfer into oocytes, the donor nucleus must undergo reprogramming of these epigenetic marks. This may involve changes of epigenetic features similar to those observed in normal embryos during early development (Santos et al., 2003). Potential applications of somatic cell nuclear transfer to agriculture and medicine are now limited by low efficiency and high rates of embryonic, fetal, and neonatal loss. The low efficiency of somatic cell nuclear transfer procedures is considered to be the result of an incomplete reprogramming of the donor somatic cell nucleus, which leads to the abnormalities in the expression of developmentally important genes. Daniels et al. (2000) demonstrated that abnormal transcription of three developmentally important genes (IL6, FGF4, and FGFr2) in morula- and blastocyststage embryos derived from nuclear transfer procedures was the reason for reduced embryo viability. Very low rate of development was noted when nuclei of mammary gland cell line were used for embryo reconstruction (Wilmut et al., 1997). Animal cloning experiments in which granulosa cells are frequently used as nuclear donors (Polejaeva et al., 2000; Park et al., 2001) also bring evidence for stem cell characteristics of GC. Cloning efficiency was significantly increased when bovine (Gibbons et al., 2002) and goat (Keefer et al., 2002) granulosa cells were used as nuclear donors. Batchelder et al. (2004) found that cloned bovine blastocysts developing from the nuclei transferred from preantral follicle granulosa cells, the least differentiated in the lineage, progressed significantly better through implantation process and into later stages of pregnancy in comparison with blastocysts derived from nuclei from terminally differentiated granulosa cells and luteal cells. Batchelder et al. (2008) also showed that using cumulus and granulosa donor cells resulted in a greater proportion of viable day-7 embryos in comparison to ear-skin cells. Akagi et al. (2008) demonstrated improvement of developmental competence after the transfer of cumulus cell nuclei using in vivo-matured oocytes as recipient cytoplasts in cattle. As postulated by Rodgers et al. (1999), the success of cloning from granulosa cells is due, partly at least, to the stem cell character of some of the granulosa cells, and using the nuclei from granulosa cells of primordial follicles for embryo reconstruction would be predicted to have an even higher success rate.

In conclusion, although there is some evidence indicating stem cell properties of granulosa cells, it should be stressed that so far there has been a lack of evidence to prove the presence of asymmetric division, the real nature of pluri- and- multipo- 
tency and undefined self-renewal capabilities in granulosa cells, which are major points characterizing stem cells. It is known that granulosa cells are involved in development of $2-5 \%$ of all ovarian cancers (Chang et al., 2009). Cancer can be a debilitating disease and therapies used to treat the cancers can also have major longterm consequences. Chemo- or radiotherapies often leave young women infertile following treatment. These therapies damage follicles in the ovaries, but still little is known about this process and mechanisms. Stem cells in adult tissues are important for repairing and renewing tissues throughout life. It is still important to get to know more about these cells in the ovary. This knowledge will lead to better strategies on how to protect them, not only from chemo or radiation therapy, but also environmental chemicals. Further research will have important clinical relevance in addition to scientific impact.

\section{Acknowledgments}

The author thanks Samuel Booker for editorial assistance with the manuscript.

\section{References}

Akagi S., Kaneyama K., Adachi N., Tsune ishi B., Matsukawa K., Wat anabe S., $\mathrm{K} \mathrm{u}$ b o M., T a k a h a s h i S. (2008). Bovine nuclear transfer using fresh cumulus cell nuclei and in vivo- or in vitro-matured cytoplasts. Cloning Stem Cells, 10 (1): 173-80.

Batchelder C.A., Hoffert K.A., Bertolini M., Moyer A.L., Anderson G.B. (2004). Development of bovine nuclear transfer embryos cloned from follicular donor cells in sequential stages of differentiation. Reprod. Fertil. Dev., 16, p. 123.

B a t c h e $1 \mathrm{~d}$ e r C.A., H o f f e r t K.A., B e r to 1 i n i M., M o y e r A.L., M a s o n J.B., P e t k o v S.G., F a m u l a T.R., A n d e r s o n G.B. (2005). Effect of the nuclear-donor cell lineage, type, and cell donor on development of somatic cell nuclear transfer embryos in cattle. Cloning Stem Cells, 7 (4): $238-254$.

Byskov A.G., Lintern-Moore S. (1973). Follicle formation in the immature mouse ovary: the role of the rete ovarii. J. Anat., 116: 207-217.

Chang H.L., MacLaughlin D.T., Donahoe P.K. (2009). Somatic stem cells of the ovary and their relationship to human ovarian cancers. (April 30, 2009), StemBook, ed. The Stem Cell Research Community, StemBook, doi/10.3824/stembook.1.43.1, http://www.stembook.org.

Chronowska E., Tomanek M., Kott T. (2009). Effect of aromatase inhibitor (fadrozole) on proliferation, estradiol production and telomerase activity in pig granulosa cells in vitro. Czech J. Anim. Sci., 54: 566-574.

Chronowska E., Tomanek M., Kott T. (2010). Effect of antioestrogens on proliferation, differentiation and telomerase activity of pig granulosa cells in vitro. J. Anim. Feed Sci., 19: $577-589$.

Chronowska E., Kott T. (2011 a). Androgen receptor inhibitor stimulates telomerase activity of pig granulosa cells in vitro. Anim. Sci. Pap. Rep., 29 (4): 313-323.

Chron ow sk a E., Kott T. (2011 b). Optimization of conditions of prolonged culture of pig granulosa cells in vitro. Ann. Anim. Sci., 11 (3): 383-392.

Copper G.M. (1997). The cell, a molecular approach. Oxford University Press, London, pp. 604-608.

Daniels R., Hall V., Trouns on A.O. (2000). Analysis of gene transcription in bovine nuclear transfer embryos reconstructed with granulosa cell nuclei. Biol. Reprod., 63 (4): 1034-1040.

D a sh e R., F i e d l e r W., E r n s t G. (1997). Telomers and telomerase: biological and clinical importance. Clin. Chem., 43: 708-713. 
Gibbons J., Arat S., Rzucidło J., Miyoshi K., Waltenburg R., Respess D., Vena ble m A., S tice S. (2002). Enhanced survivability of cloned calves derived from roscovitinetreated adult somatic cells. Biol. Reprod., 66: 895-900.

Gond os B. (1975). Surface epithelium of the developing ovary. Possible correlation with ovarian neoplasia. Am. J. Pathol., 81: 303-321.

Goto H., Iwat a H., Take o S., Nisinosono K., Murakami S., Monji Y., Kuwayama T. (2011). Effect of bovine age on proliferative activity, global DNA methylation, relative telomere length and telomerase activity of granulosa cells. Zygote (in press).

Gutierrez C.G., Ralph J.H., Telfer E.E., Wilmut I., Webb R. (1997). Growth and antrum formation of bovine preantral follicles in long-term culture in vitro. Biol. Reprod., 62: $1322-1328$.

Honda A., Hirose M., Hara K., Matoba S., Inoue K., Miki H., Hiura H., Kanatsu - Shinohara M., Kanai Y., Kono T. Shinohara T., Ogura A. (2007). Isolation, characterization, and in vitro and in vivo differentiation of putative thecal stem cells. Proc. Natl. Acad. Sci. USA, 104: 12389-12394.

H un t e r M.G., P a r a d is F. (2009). Intra-follicular regulatory mechanisms in the porcine ovary. Soc. Reprod. Fertil. Suppl., 66: 149-164.

Ke efer C.L., Keyston R., Lazaris A., Bhatia I., B e gin I., Bilodeau A.S. (2002). Production of cloned goats after nuclear transfer using adult somatic cells. Biol. Reprod., 66: 199-203.

K inugawa C., Murakami T., Oka mura K., Y a j i ma A. (2000). Telomerase activity in normal ovaries and premature ovarian failure. Tohuku J. Exp. Med., 190: 231-238.

Kossowska-Tomaszczuk K., De Geyter C., De Geyter M., Martin I., Holzgreve W., S cherberich A., Zhang H. (2009). The multipotency of luteinizing granulosa cells collected from mature ovarian follicles. Stem Cells, 27: 210-219.

L a vran os T.C., M a th is J.M., L a t a m S.E., Ka li on is B., Sh a y J.W., R od g e r s R.J. (1999). Evidence for ovarian granulosa stem cells: Telomerase activity and localization of the telomerase ribonucleic acid component in bovine ovarian follicles. Biol. Reprod., 61: 358-366.

Park K.W., Kuhholzer B., Lai L.X., Machaty Z., Sun Q.Y., Day B.N., Prather R.S. (2001). Development and expression of the green fluorescent protein in porcine embryos derived from nuclear transfer of transgenic granulosa-derived cells. Anim. Reprod. Sci., 68: 111-120.

P inkerton J.H., M c K a y D.G., A d a m s E.C., Hertig A.T. (1961). Development of the human ovary - a study using histochemical technics. Obstet. Gynecol., 18: 152-181.

Polejaeva I.A., Chen S.H., Vaught T.D., Page R.L., Mullins J., Ball S., Dai Y., B o on e J., W a 1 ke r S., A y a re s D.L., Colman A., C a m p b e 11 K.H.S. (2000). Cloned pigs produced by nuclear transfer from adult somatic cells. Nature, 407: 86-90.

P ot te n C.S., L o e ffle r M. (1990). Stem cells: attributes, cycles, spirals, pitfalls and uncertainties. Lessons for and from the crypt. Development, 110: 1001-1020.

Rodgers R.J., Lavranos T.C., R odger s H.F., Y o ung F.M., V e 11 a C.A. (1995 a). The physiology of the ovary: maturation of ovarian granulosa cells and a novel role for antioxidants in the corpus luteum. J. Steroid Biochem. Molec. Biol., 53: 1-6.

Rodgers H.F., Lavranos T.C., Vella C.A., R odgers R.J. (1995 b). Basal lamina and other extracellular matrix produced by bovine granulosa cells in anchorage-independent culture. Cell. Tissue Res., 282: 463-471.

R odgers R.J., Vella C.A., R odgers H.F., S c ott K., Lavranos T.C. (1996). Production of extracellular matrix, fibronectin and steroidogenic enzymes, and growth of bovine granulosa cells in anchorage-independent culture. Reprod. Fertil. Develop., 8: 249-257.

Rodgers R.J., Lavranos T.C., van W ezel I.L., Irving-Rodger s H.F. (1999). Development of the ovarian follicular epithelium. Mol. Cell. Endocrinol., 151: 171-179.

Rus so V., Berardinelli P., Martelli A., Di Gioacinto O., Nardinocchi D., Fant a s i a D., B u rb on i B. (2006). Expression of telomerase transcriptase subunit (TERT) and telomere sizing in pig ovarian follicles. J. Histochem. Cytochem. 54: 443-455.

Santos F., Zakhartchenko V., Stojkovic M., Peters A., Jenuwein T., Wolf E., R e i k W., D e a n W. (2003). Epigenetic marking correlates with developmental potential in cloned bovine preimplantation embryos. Curr. Biol., 13 (13): 1116-1121. 
Tomanek M., Chronow ska E., Kott T., Czernekova V. (2008). Telomerase activity in pig granulosa cells proliferating and differentiating in vitro. Anim. Reprod. Sci., 104 (2-4): 284-298.

W i 1 mut I., S chnieke A.E., M c Wh ir J., K ind A.J., Ca mp be 11 K.H.S. (1997). Viable offspring derived from fetal and adult mammalian cells. Nature, 385: 810-813.

W o b u s A., B o h e 1 e r K. (2005). Embryonic stem cells: prospects for developmental biology and cell therapy. Physiol. Rev., 85: 635-678.

Y a m a gat a Y., Naka mura Y., Uma y a hara K., Harada A., T a ka y a ma H., S ug ino N., $\mathrm{K}$ a to H. (2002). Changes in telomerase activity in experimentally induced atretic follicles of immature rats. Endocrine J., 49: 589-595.

Accepted for printing 13 II 2012

\section{EWA CHRONOWSKA}

\section{Macierzysty charakter komórek warstwy ziarnistej - przegląd}

\section{STRESZCZENIE}

Większość dotychczas przeprowadzanych badań nad komórkami macierzystymi w obrębie jajnika koncentrowała się na komórkach płciowych. Jednakże w ostatnim czasie zauważa się wzrastające zainteresowanie somatycznymi komórkami macierzystymi żeńskiej gonady, głównie z powodu ich potencjalnego związku z rozwojem raka jajnika. Obecność komórek macierzystych w obrębie osłonki pęcherzykowej oraz nabłonka powierzchniowego jajnika została dobrze udokumentowana. Z drugiej zaś strony wciąż brak przekonujących dowodów na macierzysty charakter komórek granularnych. Celem niniejszej pracy jest przegląd aktualnej wiedzy na temat macierzystego charakteru komórek tworzących główny somatyczny komponent jajnika - komórek granulozy. 